\title{
Public Service Innovations and Changing Ethos in Africa
}

OKAFOR, Chukwuemeka | FATILE, Jacob Olufemi | EJLONIBU, Ganiyu L

\section{Abstract}

$\mathrm{O}$ ne of the widely held beliefs in public management is that strict commitment to an ideology of public service values, which is a critical factor in the delivery of public services. However, with the introduction of market-oriented reforms-innovations, most of these values face severe and serious challenges. This study, using a comparative and analytical method, examines the principles which underpin the African governments' program of innovation in public service delivery and in particular the traditional public service ethos. The article reveals that over the years, African public services and those who work in them fall short of the ideal leading to the attempt to innovate by introducing the market values which have equally raised questions about possible threats to the ethos. After identifying some challenges that innovation may pose, the article suggests that traditional public sector ethos should be redefined to allow for innovative ideas in service delivery. Finally, the study concludes that a new "synthesized" ethos that draws on the core elements of bureaucratic principles as well as market based values, would deliver superior public services.

Keywords: Public Service, Public Service Delivery, Innovation, Public Service Ethos, Market values. 


\section{Introduction}

In the last twenty-five years, there has been a growing realization both from international realm and within the continent that the African public sector organizations should learn how to innovate if they are to respond adequately to a rapidly changing environment and citizens' expectations. The recent push for public sector innovation has a variety of drivers behind it; most prominent among them is the need to provide prompt, improved and personalized public services to citizens. Thus, innovation has been central to many reform initiatives undertaken by African governments' public sector organizations (United Nations, 2007: ix).

Today, it is evidently obvious that life for employees in the public sector has changed dramatically and greater organizational change is happening in government bureaucracies not only in Africa but also around the globe. Competition and contracting are powerful drivers of that organizational change. However, what does 'good' innovation such as competition and contracting mean in relation to public services? Perhaps we may say value for money is a part of the answer, but only a part. When it comes to the design of public service markets as noted by Reddington (2004: 10), it also matters to know whether a contract is politically sustainable or not. The service of the public is a thing which cannot be put to auction and struck down to those who will agree to execute it the cheapest. When the proportion between reward and service is our object, we must always consider of what nature the service is, and what sort of men they are that must perform it. Public services are different because they must (in most cases) be consumed collectively. They are different because they raise complex issues of equity, access and affordability. They are different because failures are judged politically and not proportionately. The design and management of politically sustainable public service markets must have regard to these complexities (Sturgess, 2006: 4).

The depth and breadth of public sector changes have led to heated arguments centred on the role of the government in contemporary society, on the ethos of the public sector and the managerial culture of administration. For example, Tait (2005: 124) doubts whether we can be confident that competition and contracting will be consistent in delivering these results? Are public service markets politically sustainable over the medium to long term? For the early political economists, the answer was self-evident. By carefully designing performance incentives, government could harness commercial selfinterest to serve public ends, even in complex services such as prison management. As 
the great Utilitarian, Jeremy Bentham expressed it, contractual rewards and penalties would join interest with duty, and that by the strongest cement that can be found.

This article therefore addresses the research gap by examining one prominent aspect of traditional public administration (public service ethos-values) by outlining the 'shift' from old public administration to new public management and considers the principal expression of the 'new' such as competition and contracting for complexity and their implications on the traditional public service ethos in Africa. Finally the study agrees with the submission of Clarke (2002:7) who opines that "reform (innovation) must always respect the powerful public service ethos and it must acknowledge the contribution and skills of those who now work in the public sector. The ethos of public service is as intrinsic to public service as the practice itself, helping to create and manage the expectations and aspirations of all stakeholders."

\section{Conceptual and Theoretical Framework}

Public Services in the view of Aldridge and Stoker (2012: 16) were created to improve the quality of people's life. According to them, public service can be defined as one that relies upon element of taxpayer's money to establish or sustain the service through part or whole subsidy in order to contribute to community well-being. They argue further that public service accepts a different and extended type of accountability. That is, politicians and managers of public services have to justify why they allocate and ration resources in the way that they do and those services in turn are subject to a form of democratic accountability and scrutiny. But more critically, the term public service indicates a wider scope than the civil service. He argues further that public service can be defined as the machinery of government, that is, the totality of services that are organized under public (that is, government) authority (Lane, 1993:4). Thus public service is the totality of the administrative structures within which the work of government is carried out.

Following from the above definitions we realized that a semantic distinction is often made between "civil service" and "public service." This is in accordance with the linguistic nuance introduced by Aeberhard with reference to the French Language. Aeberhard cited in the French function of "Publique," a generic term that covers all permanent state personnel and municipal staff, whereas "Le service public" describes public utilities of 
general benefit to the population, controlled by governments (Olaopa, 2008: 57). The current trend in terminology and particularly in this research is public goods or services provided by government to its citizen.

In the modern age, the definition of public service is increasingly becoming complex and blurred. For example, many would argue that bus services remain an essential public service but they are almost entirely provided by private sector, while telecommunication services are virtually provided by private businesses with the regulatory role being left to government. Public services are key determinant of quality of life that is not measured in per capita income. They are also an important plank of essential service delivery. Public services then refer to services provided by a government to its citizens either directly through the public sector or by financing and regulating private provision of services (Aldridge and Stoker, 2012: 10).

Public Service Delivery is another comprehensive and relevant concept in the study. Contextually, public service delivery is the result of the intentions, decision of government and government institutions, and the actions undertaken and decision made by people employed in government institutions. It has an impact on human development directly if it is delivered to people in the form of basic services such as education, health, water and sanitation which contribute to promoting human development (Rakate, 2006: 3). Mitel (2007: 2) observes that public service delivery has been one of the key functions of the public sector. Citizens and businesses alike expect convenient access to government services and information through multiple channels; such as telecommunication, agriculture, transportation, education, etc. Many government agencies have traditionally functioned as separate business units, resulting in complex and disjointed communications. This has led to inefficiencies and service ineffectiveness, which serves to drive up costs. Thus, meeting increasing service demands with fewer resources under constrained budgets has been a major challenge for most governments.

Innovation is also described as the application of new ideas to produce better outcomes. It is a means to an end, not an end in itself. An appreciation of the importance and diversity of innovation, and how to achieve it, should be part of the knowledge, skills and behaviours of every public servant. Innovation goes beyond creativity or the generation of new ideas. It is a process that can be replicated. Innovation can take any number of forms (Australian National Audit Office, 2009: 2). 
Some innovation may be ground-breaking or transformational in the sense that it represents a substantial departure from the past.

Public sector management innovation can therefore be defined as the development of new policy designs and new standard operating procedures by public organizations to address public policy problems. Thus, an innovation in public administration is an effective, creative, and unique answer to new problems or a new answer to old problems. Furthermore, an innovation is not a closed and complete solution, but an open solution that can be transformed by those who adopt it. It refers to putting new ideas into useful practice (UNDESA, 2007: 7). In a public sector context, innovation could be described as the 'creation and implementation of new processes, products, services and methods of delivery which result in significant improvements in the efficiency, effectiveness or quality of outcomes (Mulgan and Albury, 2003: 5).

Public Service Ethos (PSE) is used in this paper in reference to "principles of conduct" or "standards of behaviour" which regulate professional practices. Thus, public service ethos (values) is considered as "enduring beliefs that influence the choices public servants make from among available means and ends" (Kernaghan, 2002: 2). Woodhouse (1997: 1) describes it as an amalgam of beliefs and norms or conventions of behaviour (concerning Public Service). This ethos serves as an ethical core or code for Civil servants and officials. PSE also has a motivational aspect (Reeves, 2004: 25). Perry and Wise's work was central in raising interest in the public service motivation construct. According to them it 'refers to an individual's predisposition to respond to motives grounded primarily or uniquely in public institutions (Perry and Wise, 1990: 369).

A number of theories have emerged which, in one way or another, influenced most of the initiatives implemented under public sector innovation (reform) in Africa. These include New Institutional Economics (NIE), public choice theory, development theory and New Public Management (NPM). However, for the purpose of this study, the NPM theory is adopted. The new public management (NPM) perspective is often associated with positive, action-oriented phrases such as: reinventing government, re-engineering, revitalization of the public service, organizational transformation, total quality management, paradigm shift, entrepreneurship, empowerment, results-over process, downsizing-and 'rightsizing', lean and mean, contracting out, offloading or outsourcing, steering rather than rowing, empowering rather than serving, and earning rather than spending (Frederickson, 1996: 551). 
NPM captures most of the structural, organizational and managerial changes that took place in the public services both in developed (especially in the OECD countries such as the UK, New Zealand and Australia) and developing countries (especially Africa) in the late 1970s. It is a body of managerial thought or an ideological thought system based on ideas generated in the private sector, and imported into the public sector (Hood, 1995: 106). NPM shifts the emphasis from traditional public administration to public management, and pushes the state towards managerialism. The traditional model of organization and delivery of public services, based on the principles of bureaucratic hierarchy, planning, centralization, direct control and self-sufficiency, is replaced by a market-based public service management or 'enterprise culture' (Larbi, 1999: 7; Walsh, 1995: 13).

The emergence of the neo-liberal agenda in the form of "rolling-back the state" in some of the most developed (western) nations in the 1970s, began to have expression in IMF and World Bank supported economic reform programmes in African countries in the 1980s, with a similar demand for smaller, efficient and cost effective public administration institutions which could only be achieved through reforms (Caiden 1991: 148; Denhardt and Denhardt, 2000: 549). Thus, during the 1980s, the doctrinal components of NPM started evolving and it was fully expanded globally in 1990s. For example, the core ideas of the UK's 'citizens' charter' initiative, launched in 1991, added a consumerist dimension to public management. This charter brought the issue of consumers to prominence and has since become a key feature of most of NPM discussions and thus forming a good innovative idea which other countries especially Africa could emulate (Hood, 1991: 5).

In recent years, most African countries have adopted the New Public Management (NPM) approach to Public Sector innovation. This initiative is described by some authors as "a label used to describe a management culture that emphases the centrality of the citizen or customer, as well as accountability for results..." NPM shifts the emphasis from traditional public administration to public management, pushing the state towards 'managerialism'. The traditional model of organization and delivery of public services based on the principles of bureaucratic hierarchy, planning and centralization, direct control and self-sufficiency, is apparently being replaced by a market-based public service management or enterprise culture" (Economic Commission for Africa cited in Sekatle, 2008: 5). Since the 1990s, a number of countries have implemented far-reaching 
public sector reform programmes. The core elements of these programmes are identified as follows:

- Creation of an enabling environment for private sector participation in the economy and protection of individual property rights;

- Enactment of anti-corruption laws, establishment of watch-dog bodies, and enforcement of ethical and accountability codes;

- Reactivation of the public service's professional values, and inculcation of the ethos of responsiveness, transparency, and accountability in service delivery agents (Balogun, 2003: 11).

Key components of the NPM may be divided into two strands. The first consists of ideas and themes that emphasize managerial improvement and organizational restructuring: managerialism in the public sector. These clusters of ideas tend to emphasize management devolution or decentralization within public services. The second strand contains ideas and themes that emphasize markets and competition. In practice, these strands overlap. There is effectively a continuum ranging from managerialism at one end, for example, decentralization and hands-on professional management, to marketization and competition at the other, for example, contracting out (Gow and Dufour, 2000: 575).

The NPM, as earlier on indicated, is characterized by its emphasis on reduction and deregulation of bureaucracy, employing market mechanisms or semi-market entities to conduct government action, devolution of responsibility downward and outward in organizations, and energizing the workforce to think in entrepreneurial terms. Thus, jettison the old values of public service and implementing the NPM reformers which sought to split policy oversight of public service providing bureaus into smaller manageable units. Scholars regarded the NPM as an international paradigm shift and debated over its efficacy. Still, academic sceptics dismissed the NPM as not delivering on its full promises, especially in developing countries (McCourt and Minogue, 2001: 2).

\section{Public Service Ethos and Innovation: A Nexus}

Historically, the study of public service ethos (PSE) is rested on the crossing point of diverse academic disciplines such as Organizational Psychology, Organizational Theory, 
Public Administration and Economics (Koumenta, 2009: 1). This partly explains the different terminologies often used by various scholars and commentators. For instance, in the field of public Administration the terms public service ethic, public sector ethos, and public service ethos have traditionally been adopted by researchers (Horton, 2006: 534; Hebson et al., 2003: 483) whereas Psychologists and organizational theory researchers have favoured the term public service motivation (Perry and Wise 1990: 368). While Labour Market Economics use the term Pro-Social Motivation to describe the preferences of agents and Pro-social Behaviour and Donated Labour to describe their action (Gregg, et al, 2008: 2). Administrative Ethics is also common to the researches in the field of Public Administration (Laxmikanth, 2011: 325).

Many research studies have shown that those working in the public services subscribe to a specific public service ethos, to a great extent this is manifested in a high level of motivation to serve the public good. As indicated above, the available literatures show that scholars have diverse opinion and use different concepts when referring to public sector values. The term public service ethos refers to tendencies that propel individuals to 'perform meaningful public service by helping others, furthering the common good and serving the public interest' (Brewer, Ritz and Vandenabeele, 2012:1). It is therefore understood as a 'cluster of motives, values, and attitudes on serving the public interest'. To Pratchett and Wingfield (1994: 2) ethos is a common set of cultural values and attitudes that are shared by staff across a range of public institutions and agencies and that inform their behaviour within them.

Usually in literature, Public Service motivation is commonly equated with the traditional values and ethos of public administration. For example, Perry and Wise quoted in Meyer et al., (2013: 4) note that 'what has historically been called the public service ethic...is defined more formally...as public service motivation'. While Perry and Wise (1990:368) refer to this value as Public Service Motivation conceptualize it as 'an individual's predisposition to respond to motives grounded primarily or uniquely in public institutions and organizations'. Contrary to Perry and Wise's definition of PSM as a 'predisposition' the authors recognise that how individuals interpret such values is also influenced by the environment in which they find themselves in.

The role of the environment is also recognised by Vandenabeele et al., (2006: 325) who describe public service motivation as the beliefs, values and attitudes that go beyond self-interest and organizational interest that concern the interest of a larger 
political entity and which induce through public interaction motivation for targeted action. Also, Perry and Hondeghem (2008: 295) argued that 'a specific expression of prosocial, other-oriented motives, goals, and values' is what distinguishes public from private sector employees. It is assumed that the portfolio of tasks and activities in the public domain provides greater opportunities to satisfy such needs and therefore attracts individuals with matching values.

However, public service delivery demands structures not only to make the civil service adhere to impartiality, integrity, objectivity, selection and promotion on merits, but also to give value for money and high quality services that customers want. Generally speaking, public administration has come to be associated with delays, red-tape, insensitivity and inefficiency in the regulation of cost and time more particularly in Africa. Yet, the traditional values of public bureaucracies continue shielding people even when they are non-productive. This gave rise to a gap in the structure with its rigid management. Dissatisfaction with the single integrated public service structure, which has an adherence to formalised processes and procedures, led to a new institutional structure with new public management concerned with the use of resources to achieve results which evolved in the $20^{\text {th }}$ century. Such principles of managerial techniques from the private sector have been injected into public sector services. This in turn changes the methods of leadership in public administration, the move from the traditional managerial skills of planning, organising, directing, coordinating and controlling, to the new public managerial skills involving 'motivation, inspiration, communication and coaching' (Barker and Rubycz, 1996: 4; Barron and Scott, 1992: 528).

So, in a context of increasing demand from service users and tax payers for more and better services, African governments introduced market values such as performance management, profit-oriented and cost-minimizing reforms in public sector. Therefore the introduction of public service innovation is about creating 'a better life for all' and ensuring that the alignment between political and administrative goals, the deployment of government resources and the needs of citizens, result in an improvement in the lot of the masses who constitute the majority in the society. The most recent example of the objective to associate "ethos" with both sectors is the seventh Report of the Public Administration Select Committee (PASC) commissioned by the Labour government and published in 2002. The report asserts that a strong ethos is not a public sector monopoly, and that many examples of successful private sector provision exist. In 
particular, it argues: Public sector and public service are not identical. Nor is it possible to sustain the view that public sector workers always display a service ethos, or that private sector workers do not' (Ayee, 2008: 78).

\section{Antecedents of change and Innovation in African Public Sector}

The need for change and innovation in African and other developing countries' public sector institutions has been prompted largely by world-wide decline in public finances and the need 'to get more for less. It should however be noted that Present-day African countries were created by colonial governments. So, public administrative systems that may be found in African countries today were inherited from the colonial rulers in the 1960s. They were inspired by the Weberian bureaucratic model (Adamolekun, 2002: 21). The model therefore provides relevant data for understanding the challenges that new ideas have to overcome to truly become innovations and best practices in Africa. In other words, one cannot understand the functions, structure, orientation and organizational culture as well as challenges facing the civil service without looking at the strengths and weaknesses of the Weberian bureaucratic model.

The centralising impact of colonialism is evidenced in the economic conditions that most African states faced at independence. Earlier researches in Africa showed that:

When the sub-Saharan states won independence...they faced formidable constraints to development. These included underdeveloped resources, political fragility, insecurely rooted and ill-suited institution, a climate and geography hostile to development, and rapid population growth (World Bank 1981: 9).

The available literature on the need to allow for innovation in public sector (i.e., reform) shows that changes in the socio-economic conditions in the 1970s and 1980s have provided grounds for administrative reforms in both developed and developing countries (Ayee, 2008:144). These reforms, partly prompted by the world-wide economic recession of the 1970 s and 1980 s, de-emphasized the role of the state, and rather emphasized the role of the private sector in the socio-economic life of the countries concerned, a phenomenon that is referred to in the literature as the "rolling back of the state" or the "withdrawal of the state." Underpinning these reforms was the search for efficiency and effectiveness in the face of dwindling resources (World Bank, 1997: 5). This 
was elaborated in most cases into a general crusade to reorganize and modernize the public sector including the civil service (Collins, 2000: 12).

Most of these changes had their political and ideological underpinnings in the rise of neoliberal economic thinking and conservatism in both the United Kingdom and the United States in the late 1970s and 1980s, and were reflected in the concurrent shift in the strategies of the IMF and the World Bank toward a more liberal and market-oriented ideology (Collins, 2000:12). The implications for the public service were demands for a smaller but efficient and effective public service. In the process of reforms, some management techniques from the private sector were imported into the public service such as Planning, Programming and Budgeting Systems (PPBS), merit pay, Management by Objectives (MBO) and contract-based appointments (Denhardt and Denhardt, 2000: 558).

Some of the innovations that have happened in most African countries have been influenced by the implementation of structural adjustment programmes (SAPs) and New Public Management (NPM) approach. The public sector reorganization efforts in Africa were basically aimed at accruing savings, efficiency and effectiveness, and were coded as part of the growing international NPM enterprise (McCourt and Minogue, 2001: 23).

\section{Generic Principles of the Public Service Ethos}

Although some consensus has developed as to what the public service ethos is, yet its exact ingredients remain a contentious issue. Some characterize the public service ethos as a myth - a set of vague and ambiguous statements. However, some have sought to assert the reality of the ethos and to make its contents concrete (Brereton and Temple, 1999: 461). It has been expressed, in particular, by the characteristics of public servants: ideally altruistic, community oriented, impartial, professional, and loyal to the public good. Holzer (1993:11) describes the typical public servant as dedicated and motivated by a special calling to serve others, to solve challenging problems, and to improve public welfare.

Pratchett and Wingfield (1994: 4) identified accountability, impartiality and loyalty as the core elements of public service ethos. Also, writing from a United States perspective, Perry (1996:5) describes public service motivation as a multi-dimensional construct consisting of: attraction to policy-making, commitment of public interest, compassion 
and self-sacrifice. While in the case of France and Belgium, public service values are rooted in the tradition of the 'LOIS Rolland' which gives prominence to issue of equality, neutrality and fairness but American notions of self-sacrifice and patriotism are less pronounced (Hondeghem and vandanbeele, 2005: 465). Nigerian and other West African countries' Public service ethos follows the British pattern: integrity, loyalty to the nation, equality, public interest, neutrality, impartiality, fairness, sincerity, sense of public good, non-corruptiveness, non-partisan attitude, efficiency and anonymity. These values are mostly set out in their civil service code of conduct.

Table 1: Institutional Values in operation in African Public Sectors

\begin{tabular}{|c|c|c|}
\hline Dimension & $\begin{array}{l}\text { Legalistic-bureaucratic } \\
\text { Value }\end{array}$ & Managerial Value \\
\hline Rationality & $\begin{array}{l}\text { Bureaucratic, legalistic, } \\
\text { professional }\end{array}$ & $\begin{array}{l}\text { Economic (causal means-end } \\
\text { relations, rational action) }\end{array}$ \\
\hline Legitimacy & Procedural & Results-based \\
\hline Vision and mission & $\begin{array}{l}\text { State as sovereign (superior } \\
\text { position in society) } \\
\text { Serving society and the } \\
\text { public interest }\end{array}$ & $\begin{array}{l}\text { Public sector as service provider } \\
\text { Achieving objectives/targets and } \\
\text { serving clients/customers }\end{array}$ \\
\hline Core values & $\begin{array}{l}\text { Legality, correctness, } \\
\text { political neutrality, } \\
\text { objectivity, equity, loyalty, } \\
\text { security, secrecy, continuity, } \\
\text { stability }\end{array}$ & $\begin{array}{l}\text { Performance, effectiveness and } \\
\text { efficiency, prudence } \\
\text { Change, flexibility, innovation }\end{array}$ \\
\hline $\begin{array}{l}\text { Evaluation criteria } \\
\text { and focus of } \\
\text { attention }\end{array}$ & $\begin{array}{l}\text { Rules, inputs, } \\
\text { responsibilities, duties and } \\
\text { Rights Focus on } \\
\text { appropriateness of action }\end{array}$ & $\begin{array}{l}\text { Organizational and individual goals, } \\
\text { results (i.e. output and outcome) } \\
\text { Focus on consequentiality of action }\end{array}$ \\
\hline $\begin{array}{l}\text { Mode of } \\
\text { governance }\end{array}$ & $\begin{array}{l}\text { Bureaucratic governance } \\
\text { based on laws, rules, and } \\
\text { directives with strict }\end{array}$ & Contractual governance based on \\
\hline
\end{tabular}




\begin{tabular}{|c|c|c|}
\hline & $\begin{array}{l}\text { accountability towards the } \\
\text { sovereign; tight and } \\
\text { multiple controls } \\
\text { Hierarchical, centralized, } \\
\text { and united system }\end{array}$ & $\begin{array}{l}\text { objectives/targets, results, } \\
\text { performance measures, and } \\
\text { management tools in a competitive } \\
\text { environment } \\
\text { Decentralized and fragmented } \\
\text { system } \\
\text { with strong managerial autonomy }\end{array}$ \\
\hline $\begin{array}{l}\text { Employment } \\
\text { status }\end{array}$ & $\begin{array}{l}\text { Sector-specific, highly } \\
\text { regulated, special status } \\
\text { (life-time tenure) in order to } \\
\text { guarantee neutrality Closed } \\
\text { recruitment and career } \\
\text { paths based on seniority. }\end{array}$ & $\begin{array}{l}\text { Sectoral openness based on private } \\
\text { sector employment laws } \\
\text { Flexible and open career paths based } \\
\text { on performance }\end{array}$ \\
\hline
\end{tabular}

Source: Public Sector Values (adapted from Meyer and Hammerschmid, 2006: 111)

Until now, there have been several attempts to draw parallels between the types of public administration systems and the amount of ethical problems in the public service. Contrary to the rich discussion about exact features of different paradigms in public administration, Lynn (2001: 11) recognizes that there are two main traditions in the field of public administration - Old Public Administration and New Public Management (see table 1 above). Pure models of ethics management or public administration theories do not exist in practical life. It is possible to follow only the general tendencies occurring in reality and each government has to define its own path.

The rise of ethical problems in public service is usually taken as by-products or coinfluences of changes in the public administration system (Maesschalk, 2004: 466). Denhardt and Denhardt (2000: 550) contend that "New Public Management refers to a cluster of ideas and practices that seek to use private-sector and business approaches in the public sector." During the last two decades, massive reorganisations have ripped through all levels of government and its personnel. Fundamental rethinking of the role and functioning of bureaucracy has come about. "While NPM in the 1980s was primarily 
focused on promoting more efficient and effective government service, the attention in the 1990s included issues such as equity, integrity and so forth.

However, most critics are of the opinion that implementing NPM measures in Africa may have contributed to the realisation that market-inspired reforms of government 'failures' do not work very well in conditions where the state remains weak and subject to informal influences. NPM has not succeeded in eliminating the clientelistic tendencies that tend to permeate African governments. In such a context, the creation of independent agencies is a step in the right direction. But owing to the manner in which NPM has been introduced as a 'technocratic' fix, its full effectiveness cannot be achieved.

\section{Two Phases of Challenge: Managing Innovation and Sustenance of Ethos}

Innovation and continuous improvement are essential to the sustainability of public sector transformation. The first phase challenge recognized in this paper is that, in the public sector organizations, it is harder to be an individual and think of an idea. In many ways, innovation was stifled. But "the reality of the public sector today is that it should be assessed by the efficiency of its service delivery. No longer should the effectiveness of the public sector be measured by the revenue it generates or the employment it provides." Specifically, the following reasons account for the failure of public sector innovations in Africa (Chandrashekhar, cited in PricewaterhouseCoopers, 2007: 6; Olowu, 1999: 26).

There have been several criticisms about the lack of initiative and the resultant attitude of public servants in Africa, which include malingering, apathy, laziness, client insensitivity, abuse of power, misuse of good resources and absenteeism. These negative tendencies have affected job performance, contributing to inefficiency and low productivity and above all have been unfriendly to innovative ideas. Customer focus is often challenged by public sector cultures, hierarchical organisational structures and differing agency priorities. Shifting from a bureaucratic regime to a contractual one may be very challenging and it may take some time to adjust to the greater freedom which is enjoyed in the private sector. The above position has been corroborated in the word of Al Gore who observed that the problem is not lazy or incompetent people; it is red tape and regulation so suffocating that they stifle every ounce of creativity. The government is filled with good people trapped in bad systems: budget systems, personnel systems, 
procurement systems, financial management systems, information systems. When we blame the people and impose more controls, we make the systems worse (Al Gore, quoted in Mathias \& Reddington, 2006:2).

It has been noted that declining civil service morale is an impediment to the implementation of NPM techniques. The argument is that public sector innovation is unlikely to be successful if public servants regard themselves as being involuntarily pledged to perform to externally imposed standards without commensurate remuneration. Factors that constitute fear in this regards include:

- Fears of being measured and increased possibility of loss of jobs;

- Fears that staffs do not have the necessary skills;

- Increased paper work and workload; and

- Health and safety concerns (Lam, 1997: 4)

These fears underlie the resistance to changes embodied in the NPM. Poor pay and inconsistent management practices in many African public services have also contributed to low morale.

Also in African public sector, the culture or sources of organizational behaviour is defined as paradoxical, as it includes both positive and negative forces (Whorton \& Worthley, 1981: 357). Values reflected by government organizations have been somewhat inconsistent and contradictory over time. From the literature we can deduce both negative and positive concepts. A negative view reveals a bureaucratic culture characterized by constraints within government agencies, portrayed as rigid, stifling, and contributing to organizational ineffectiveness in the delivery of public services. The popularized view of government bureaucracies challenges more positive, ideological concepts of government organizations as imbued with the public service ethos, characterized by commitment to the public interest and to the common good. Pittegrew (1979:570) argued that conflicting ideas about government employment impede entry into public service, because, in order for people to function within any given setting, they must have a secure sense of that reality.

Other issues that constrain public service innovation in Africa are inappropriate work habits, corruption and lack of appreciation of time. African countries have realized that if their countries are to achieve developmental goals, become more competitive and attract the necessary foreign investment, then there is a need to reorient the public 
service workforce and inculcate it with new work ethics and values. Colloquially speaking, bureaucratic value means red tape, over-controlling bosses, and apathetic employees. All of these are seen as the product of formalized organizations that stifle innovation (Alder, 1999: 38; Alder \& Borys, 1996: 63). The dilemma is that an important motive of formalization is to protect the public's interests. Hegel saw bureaucrats as mediating between constitutional norms and concrete situations, subsuming the particular into the universal, and concretizing universal norms (Shaw, 1992: 382).

Moreover, despite some of the successes of public sector innovation in African countries, scholars such as Olowu (1999: 17) have pointed out that the majority of innovation efforts have failed because they do not address the serious human resource problems confronting the public services in the countries concerned. Their diagnosis and prognosis, as well as their strategies of reform implementation, have all been faulty.

However, the second phase of the challenge recognized by this paper is the sustenance of traditional public service ethos. In this era of government outsourcing, where the cultural context of public service delivery is changing, and the presence of traditional concepts of public service ethos among scholars has been questioned (Light, 2003: 3). In today's world, public sector is no longer the place for selfless public servant but rather those in the private sector. The "corporatist culture" or "managerialist" movement has severely challenged the integrity of public servants who are under the scrutiny of normative moral standards of moral conduct as opposed to the blatantly selfinterested behaviour justified by measurable performance borrowed from business.

So, one of the major challenges to public sector management innovation is the declining social value of society itself. Values such as integrity, honesty, dependability, helpfulness, impartiality, courteousness, and fairness are gradually disappearing from the public services (Agere and Mendoza, 1999: 26). Unfortunately, in most African societies, there is no system for reinforcing these values.

These new values derive from, in part, recognition of market forces and customer sovereignty, which, it is argued, is antithetical to the ideology of the public interest (Hebson et al., 2003: 489). The literature indicates that, on the whole, these reforms have significantly and negatively affected public service professionals and the public service ethos. Thus, public service innovation (restructuring) which started over three decades ago continues posing serious challenge to the classical approach of administration to bring about organizational change in public sector management. For instance the New 
Public Management encourages the contractual approach to public services delivery where, instead of relying on a rule-based administrative approach, government hires managers who contract with public and private organizations in a deregulated market, thereby introducing some level of competition (Lane, 2006:7). Thus, in the global world, public sector innovation is creating a 'mixed economy' and gradually the sector is becoming more competitive with private, voluntary and independent providers, increasingly delivering public services alongside public organisations. This has resulted in some public sector organisations transforming to the private and for-profit organizations. This has been viewed by some scholars as a deliberate effort to jeopardize public interest.

NPM shifts the emphasis from traditional public administration to public management, pushing the state towards 'managerialism'. Traditional model of organization and delivery of public services, based on the principles of bureaucratic hierarchy, planning and centralization, direct control and self-sufficiency, is apparently being replaced by a market-based public service management or enterprise culture. Though in all European countries changes and innovations accompanying the movement to managerialism and New Public Management have had a great impact, however, Frederickson (2005: 178) warns that "the managerial recipe - deregulation, privatizing, downsizing, and market competition - will make a dish that will spoil and become the problems of future, and these problems will be primarily ethical."

\section{The Way Forward}

Flexible innovations instead of rigid adherence to law should be encouraged as this will impact positively on service delivery. Whether it is in accessibility or cost effectiveness, the bottom line is that citizens will realise change in their lives after interacting with an effective Public Service. Also, resources are not unlimited. Innovative ways will ensure that public servants make most of what they have to deliver service to the public. So, every public organisation must be inclined towards innovation. Everyone must understand the vision of a 'better life for all'. They must feel personally responsible for innovation. Furthermore, an innovative Public Service is best positioned to ensure that service is satisfactorily delivered to citizens. Just as the proponents of public sector innovations (reforms) argued that efficiency, effectiveness and 'value for money' should 
be prioritized over ethical considerations and the values of public servants should constantly evolve and be refined (Mayo, 2006: 10).

Also, when introducing innovations in service delivery, African public sectors must always respect the powerful public service ethos. The reason for this is that public service ethos is as intrinsic to public service as the practice itself, helping to create and manage the expectations and aspirations of all stakeholders. Without an ethos based on social justice, there is little hope of a reality which delivers it (Koumenta, 2009: 14). Public service ethos such as integrity and trust are significant in introducing any kind of reform initiative. Public sector reforms or innovation that involves changes in structures, processes and procedures would be ineffective unless these areas are accompanied by reforms in behaviour, mindsets and eventually values. Just as Ayee (2008: 144) observes, "the success or the achievement of the objectives of the civil service depends, in part, on the resourcefulness, commitment, dedication and loyalty of its workforce."

More also, if African public services are to meet the need and aspirations of the customers and the wider community then the people employed in Public service delivery must be able to offer the best possible service to their customers and they must be empowered to do so. Thus, African Public sector needs public servants who are motivated not only by a sense of self-sacrifice but also with the provision of appropriate work conditions levels of remuneration, training, development support, and a culture that values performance and service. Based on the above argument Aldrige and stoker (2002: 15) contend that what motivates public servant is a complex issue. There are countless examples of frontline staff such as nurses or teaches who gives so much of themselves mentally and emotionally or backroom staff who stay on late at work to a make sure that the right support systems are in place to get the job done. "People given 'them all' in response to slime sense of commitment to serving the public is one way of defining the public service ethos. We know such motivation exists but we also know it does not exist in all people involved in public service all of the time. Indeed precisely because it has the quality of people who are prepared 'to go extra mile' it is an unsustainable element in maintaining effective public service delivery."

From the above argument of Aldridge and stoker, one thing is certain; staff cannot be expected to keep going extra mile every time while we refuse to build our commitment to public service on a firmer footing that can be sustained on a daily basis and in response to crisis. What is required in delivering efficient and effective service is a 
commitment that can be established through training, support and good management practice rather than been seen as mysterious product of a self - sacrificing career choice made by heroic individuals. This idea of relying only on altruism would be wrong and unethical, and cannot lead to better services. The need to separate the proper and positive contribution of volunteering should be encouraged and fostered and can make an important contribution to public service.

To the traditional values of accountability, impartiality and probity, customer service must also be included in the African public service code of conduct. Increasingly, notions of 'customer satisfaction' and model of 'customer service' traditionally associated with private sector management practice have gained prominence in the vocabulary of government officials and of reform (Koumenta, 2009: 2). According to John Reid (2004: 18), the traditional ethos of public service needs to be supplemented by an additional element of 'customer care' or as Tony Blair put it 'in public services, customer satisfaction has to become a culture, a way of life not an added extra'. Thus service delivery is contractual in nature between provider and user and it is the 'customer' that defines expectations and assesses outcomes.

There should be multiple channels for service delivery, so that customers can have 'channels of choice', depending on specific needs at specific times. Fountain (2001: 62) argues that, the efficacy of 'customer service' culture is based on the premises that customer can use 'exist' (meaning switching to other providers if the level of service falls below their expectations). However, this approach has been problematic in practice especially in government monopolies. African public sector where customers are not satisfied with the quality of treatment they received from their providers but ironically their ability to shop around for a better service is restricted.

Thus, in line with government commitment to a professional civil service, work ethics based on the following values have been emphasised: competence, dedication, integrity, objectivity, political impartiality, and selection and promotion on merit. This commitment by African leaders has led to the promulgation of a code of conduct for the civil services. The code emphasised issues relating to the following duties: to be accountable, transparent and customer and client sensitive; to comply with rules and regulations; to give honest and impartial advice to ministers; to ensure proper control of public money; to be courteous to the public; and to maintain confidentialities (Dodoo, 1998: 15). 
Finally, if Africa wants to take the right actions now to achieve and implement the above suggestions, it is believed that African Public Service must perform the following five tasks:

- Provide high-quality, forward-looking and creative policy advice;

- deliver high-quality programs and services that put the citizen first;

- maintain a culture of honesty, impartiality and fairness, with a focus on retaining public trust;

- provide flexible, agile responses to changing realities and government priorities; and

- Be effective and efficient in all its operations.

\section{Conclusion}

Innovation is motivated and driven by a variety of short, medium and long-term factors. In the public service, the driving imperative for innovation is the need to respond effectively to new and changing government and community expectations in an increasingly complex environment. In parallel with the trends and ongoing debate in respect of the distinctiveness or otherwise of the public service and the relevance of a public service ethos, it is clear that we cannot treat the public service like any other business because public service is different. It is important to retain a public service ethos founded on core characteristics including partisan neutrality, anonymity, and accountability to and through ministers. However, innovations and better practices should be allowed especially when such features impinge on good management.

The evidence in this research article shows that the traditional ethos of public service needs not to be out rightly discarded but supplemented by an additional element of customer care, or as Tony Blair put it, 'in public services, customer satisfaction has to become a culture, a way of life, not an added extra' call for a new "synthesized" ethos that draws on the core elements of bureaucratic principles of honesty and accountability as well as more market-based ones such as customer service, customer choice and value for money. The substitution of "sector" for "service" is indicative of the conviction held by recent innovations in public sector that the values traditionally associated with public sector employment can also be upheld by those delivering a public service, but are 
employed by private organisations. The new "public service ethos" therefore becomes an amalgam of principles associated with both the public and the private sector.

\section{List of References}

- Adamolekum, L. (2002). (Ed.) Public administration in African: Main issues and selected countries. Ibadan: Spectrum Printers Ltd.

- Agere, S. \& Mendoza, I. (1999). Enhancing Policy Development and Management in the Public Service. London: Commonwealth Secretariat.

- $\quad$ Alder, P. S. (1999). Building Better Bureaucracies. Academy of Management Review, 13(4): 36-47.

- Alder, P.S. \& Borys, B. (1996). Two Types of Bureaucracy: Enabling and Coercive. Administrative Science Quarterly, 41(1): 61-89.

- Aldridge, R. \& Stoker, G. (2002). Advancing a New Public service Ethos. London: New Local Government Network, NLGN

- Australian National Audit Office (2009). Innovation in the Public Sector: Enabling Better Performance, Driving New Directions. Ottawa: Commonwealth of Australia

- $\quad$ Ayee, J.R.A. (2008). Reforming the African Public Sector: Retrospect and Prospects. Dakar: Council for the Development of Social Science Research in Africa.

- Balogun, M.J. (2003). Performance Management and Agency Governance for African Development: The Search for Common Cause on Excellence in the Public Service. Addis Ababa: UNECA

- Barker, L. and Rubycz, R. (1996). Performance Improvement in Public Service Delivery. Pitman Publishing.

- Barron, A. and Scott, C. (1992). Legislation: The Citizen's Charter Programme. The Modern Law Review, 55(4): 526-46.

- Brewer, G.A., Ritz, A. and Vandenabeele, W. (2012). Introduction to a Symposium on Public Service Motivation: An International Sampling of Research. International Journal of Public Administration, 35(1): 1-4. 
- Brereton, M. \& Temple, M. (1999). The New Public Service Ethos: An Ethical Environment for Governance. Public Administration, 77(3): 455-474.

- Buchanan, B. (1975). Red Tape and the Service Ethic: Some Unexpected Differences between Public and Private Managers. Administrations and Society, 19(2): 235-249

- Caiden, G. E. (1981). Ethics in Public Service: Codification Misses the Real Target. Public Personnel Management Journal, 10: 146-152.

- Clarke, J. and J. Newman. (1997). The Managerial State: Power, Politics and Ideology in the Remaking of Social Welfare. London: Sage.

- Collins, P. (2000). State, Market and Civil Society: Towards Partnership, in Collins, P. (ed.) Applying Public Administration in Development: Guide posts to the Future. Chichester: Wiley.

- Denhardt, R. B. \& Denhardt, J. V. (2000). The New Public Service: Serving rather than steering. Public Administration Review, 60(6): 549-559

- Dodoo, R. (1998). Country Paper Ghana, Paper Deliveredat the Second Biennial Pan African Conference of Ministers of Civil Service under the theme. Public Service in Africa: New Challenges, Professionalism and Ethics held at Rabat, Morocco, 13-15

- Dunleavy, P. \& Hood, C. (1994). From Old Public Administration to New Management. Public Money and Management, 14(3): 9-16.

- Fountain, J. E. (2001). Paradoxes of Public Sector Customer Service, Governance, 14(1): $55-73$

- Frederickson, H. G. \& Hart, D. K. (1985). The Public Service and the Patriotism of Benevolence. Public Administration Review, 45(5): 547-553.

- Frederickson, G.H. (1996). Comparing the Reinventing Government Movement with the New Public Administration. Public Administration Review, 53(3): 214-229.

- Gregg, P., Grout, P., Ractliffe, A., Smith, S. \& Wind Meijer, F. (2008). How Important is ProSocial Behaviour in the Delivery of Public Services? Centre for Market and Public Organisation, Working Paper No. 008-197.

- Hebson, G., Grimshaw, D. \& Marchington, M. (2003). PPPs and the Changing Public Sector Ethos: Case Study Evidence from the Health and Local Authority Sectors. Work, Employment and Society, 69(17, 3): 481-501. 
- Holzer, M. (1993). Creative Insights into Public Service: Building an Ethical Dialogue. Public Voices, 1(1): 9-22.

- Hondeghem, W. \& Vandenabeele, A. (2005). Valuers et Motivation Dans L' administration Publique: Perspective comparative. Revenue Francaise d Administration Publique. 115: $463-480$

- Hood, C. (1991). A Public Management for All Seasons? Public Administration, 69(1): 3-19.

- Hood, C. (1995). Contemporary Public Management: A New Global Paradigm. Public Policy and Administration, 10 (2): 104-117.

- Horton, S. (2006). New Public Management: Its impact on public servant's identity. International Journal of Public Sector Management. 19 (6):533-42

- Kernaghan, K. (2005). Rediscovering Public Service: Recognizing the Value of an Essential Institution. Available@ @ttp://Laraleve.pwgsa.gc.ca/rediscover.e.html. accessed on $13 / 10 / 2014$

- Koumanta, M. (2009). Modernisation, Privatization and Public Service Ethos in the UK. Oxford: Bookes University

- Lam, J. (1997). Transforming from Public Administration to Management: Success and Challenges of Public Sector in Hong Kong. Public Productivity and Management Review, 20(4)

- Lane, J. (1993). The Public Sector: Concepts, Models and Approaches. London: Sage.

- Larbi, G.A. (1999). The New Public Management Approach and Crisis States. Geneva: UNRISD. Discussion Paper, No. 112.

- Laxmikanth, M. (2011). Public Administration for State Civil Services and Other Competitive Examinations. New Delhi; Tata Mcgraw Hill Education Private Ltd.

- Light, P. (2003). In Search of Public Service. Center for Public Service. The Brookings Institution. Wagner School of Public Policy, New York University.

- Lynn, L.E. (2001). The Myth of the Bureaucratic Paradigm: What Traditional Public Administration Really Stood For? Public Administration Review, 61(2): 144-60.

- Maesschalk, J. (2004). The Impact of New Public Management Reforms on Public Servants' Ethics: Towards a Theory. Public Administration, 82(2): 465 - 489.

- Mathias, M. \& Reddington, E. (2006). Good People, Good Systems: What public Service Managers Say. London: The Serco Institute 
- Mayo, E. (2006). More than Words. Society Guardian, 12 April

- McCourt, W. and Minogue, M. (2001). The Internationalization of Public Management: Reinventing the Third World State. Cheltenham: Edward Edgar.

- Meyer, R.E. \& G. Hammerschmid. (2006). Public Management Reform: An Identity Project. Public Policy and Administration, 21(1): 99-115.

- Mitel, I. (2007). Simplifying and Transforming Service Delivery in Government Citizen Interaction Centres. White Paper, October.

- Mulgan, G. \& Albury, D. (2003). Innovation in the Public Sector, Cabinet Office Strategy Unit. London: United Kingdom Cabinet Office.

- OECD. (1996). Ethics in Public Service: Current Issues and Practice. Public Management Occasional Paper, No. 14, Washington D.C: OECD

- Olaopa, T. (2008). Theory and Practice of Public Administration and Civil Service Reforms in Nigeria. Ibadan: Spectrum Books Ltd.

- Olowu, D. (1999). Redesigning African Civil Service Reforms. Journal of Modern African Studies, 37(1): 1-23.

- Perry, J.L. \& A. Hondeghem. (2008). Directions for Future Theory and Research, in J.L. Perry and A. Hondeghem (eds), Motivation in Public Management: The Call of Public Service. Oxford: Oxford University Press, pp. 294-313

- Perry, J. (1996). Measuring Public Service Motivation: An Assessment of Construct Reliability and Validity. Journal of Public Administration Research \& Theory (Transaction), 6(1): 5 .

- Perry, J.L. \& Wise, L.R., (1990). The Motivational Bases of Public Service. Public Administration Review, 50(3): 367-373.

- Pittegrew, A.M. (1979). On Studying Organizational Cultures. Administrative Science Quarterly, 2: 570.

- Pollitt, C. \& G. Bouckaert. (2011). Public Management Reform: A Comparative Analysis New Public Management, Governance, and the Neo-Weberian State. Oxford: Oxford University Press.

- Pratchett, L. \& Wingfield, M. (1994). The Public Sector Ethos in Local Government: A Research Report. London: Commission for Local Democracy 
- Pricewaterhouse Coopers (2007). The Road Ahead for Public Service Delivery: Delivering on the customer promise. Available@www.pwc.com, on 12/10/2014

- Rakate, N.F. (2006). Transformation of the South African Public Service. Pretoria: Research Report. University of Pretoria, South Africa.

- Reddington, E. (2004). Good people, good systems Former Public Servants Speak about Delivering Public Services in the Private Sector. Hand Court, London: The Serco Institute

- $\quad$ Reeves, R. (2004). Don't Sell the NHS Like Shampo. New Statesman, 133(4695): 24-26.

- Reid, J. (2004). We can be Consumers and Citizens. The Guardian, 13 November

- Sekatle, S. (2008). Developing Public Services Bureaucracies to Meet the Demand of the $21^{\text {st }}$ Century

- Shaw, C.K. (1992). Hegel's Theory of Modern Bureaucracy. The American Political Science Review, 86(2): 381-389.

- Sturgess, G.L. (2006). To Gladden the Heart of Miss Nightingale: Contracting for Complexity. Hand Court, London: The Serco Institute

- Tait, W. (2005). The Works of Jeremy Bentham (1843), in John Bowring (ed.), Panopticon or the Inspection-House. Dublin, 1791, Edinburgh; 4:125.

- United Nations. (2007). Innovations in Governance in the Middle East, North Africa, and Western Balkans: Making Governments Work Better in the Mediterranean Region. New York: Department of Economic and Social Affairs

- United Nations Department of Economic and Social Affairs (UNDESA) (2007). Innovations in Governance in the Middle East, North Africa and Western Balkans. New York: UN.

- Vandenabeele, W., Hondeghem, A., \& Steen, T. (2004). The Civil Service as an Employer of Choice in Belgium: How Work Orientations Influence the Attractiveness of Public Employment. Review of Public Personnel Administration, 24(4): 319-333.

- Walsh, K. (1995). Public Services and Market Mechanisms: Competition, Contracting and the New Public Management. London: Macmillan.

- Whorton, J. W., \& Worthley, J. A. (1981). A perspective on the Challenge of Public Management: Environmental Paradox and Organizational Culture. The Academy of Management Review, 6(3): 357.

- Woodhous, D. (1997). In pursuit of Good Administration-Ministers, Civil Servants and Judges. Oxford: Clarendon Press. 
Public Service Innovations and Changing Ethos in Africa 71

- World Bank (1997). World Development Report: The State in a Changing World. New York: Oxford University Press.

- World Bank (1981). Accelerated Development in Sub-Saharan Africa. Washington DC: The World Bank.

AUTHORS' CONTACT:

OKAFOR Chukwuemeka

School of Public

Administration

University of Fort Hare

Email: cokafor@ufh.ac.za
FATILE Jacob Olufemi

Department of Public

Administration

Lagos State University

Email:

jacofem@yahoo.com
EJALONIBU Ganiyu Layi

Department of Public Administration Lagos State University Email: ejalonibuganiyu@yahoo.com 